\title{
The Nature Connection
}

\author{
J. T. Trevors • M. H. Saier Jr.
}

Received: 1 October 2008 / Accepted: 2 October 2008 /Published online: 18 October 2008

(C) Springer Science + Business Media B.V. 2008

In past articles, we have commented on our common, shared biosphere and the role of humans in its destruction. One of us (JTT) recently noticed several teenagers waiting for their school buses and others walking to a bus stop on their morning trek to school. Most were plugged into their electronic music devices, despite the fact that it was one of the most glorious autumn days ever. It seemed worth pondering what music could have been more interesting than the songs of the birds, the wind gently moving through the trees, the sun rising, and the crimson colors of autumn in the hardwood trees lining the streets. Why was rock music more important to these kids than listening to and experiencing Nature before spending a day in school? Maybe because Nature wasn't considered sexy enough, or that it wasn't COOL. Yet some of these students would be studying science (Nature) that day. Their exposure would come from their teacher's words and the textbook only. Integration of classroom material with their own

J. T. Trevors ( $\triangle)$

Department of Environmental Biology,

University of Guelph,

Guelph, ON N1G 2W1, Canada

e-mail: jtrevors@uoguelph.ca

M. H. Saier Jr.

Biological Sciences, University of California at San Diego,

La Jolla, CA 92093-0116, USA

e-mail: msaier@ucsd.edu personal lives and their experiences of Nature seems too much to ask.

Individuals are considered to be entitled to free choice in most modern democratic countries, at least those with a constitution and a bill of rights. Still, many governmental and media representatives in these countries feel they have the RIGHT to impose their views on other people, thereby influencing the decision-making process so the latter people come to the "RIGHT" conclusions (in agreement with the latter's own ideology). Of course, democracy is not an all or none ideal as different "democratic" countries provide differing degrees and types of democracy. Further, belief in the RIGHT to free thought is not generally accepted in many non-democratic countries, and in those "democracies" where true democratic principles are not practiced, the IDEAL of democracy is usually still valued by the people, even when not practiced by the governmental officials. We conclude that those world citizens who live in TRUE democracies are very much in the minority.

Because of the quite universally appreciated respect for free thought in democratic countries, it is difficult for us to understand the common disconnect with Nature by humans of ANY country or age. Our suggestion is that many of the young people of our own countries, and maybe many older people as well, plugged into their ipods, start to observe the natural world in which they live, with incomplete concentration. And because of the many distractions, they observe Nature with only partial attention. They may 
try to learn by passive, or even active observation, but their attention is not maintained long enough for information to become permanently absorbed. Then they go to class, or more rarely, to the library, and try to learn by listening, reading, and asking questions. But their understanding of the natural world, obtained by personal observations of society and their surroundings, are insufficient for them to integrate the course materials with the major world problems that surround them.

We understand this, but what does it mean? And what's to be done? Is it likely that these intelligent young students of logic and science will lose their interest in the natural world? Will they never come to recognize the diversity of our biosphere? Will they ever come to understand that the biosphere supports them and provides their source of sustenance? Food production and agriculture are essential activities for our burgeoning population, but with the essentials and survival at the forefront of young people's minds, thinking only from the standpoint of immediate needs and benefits, how can they contribute to solutions of the world's greatest problems that are essential for the long-term continuance of human existence?

Some people, especially those who live in large cities, have essentially disconnected themselves from the natural world. How is it possible they lack a knowledge of evolution, biology, reproduction, the basic health sciences, and environmental health issues such as pollution and global climate change? Are our educational systems at fault, or is the bombardment of human minds with trivia responsible for their lack of interest in world affairs? And how is it that with the increase in societal complexity, comes the diminution of their learning capacities? These urbanites may ask: "What has Nature got to do with me living in an overcrowded and polluted city?" And many will think: "And what can I do about it anyway?" The answers, of course, have everything to do with one's capacity to live a meaningful, satisfying life. And the ability to integrate is essential for anyone to help solve the tremendous problems that face us. But until the connections are made, that is, until people stop living lives of disconnect, they will not be able to reach integrated conclusions.
What are the primary food, water, and fuel sources used to sustain urban societies? Where do these provisions come from, and how do they reach their destinations? What are the costs of their transportation? What amounts of fossil fuels are burnt for this purpose? Most members of society do not know. And worse, most don't even care as long as they get what they need and desire. What processes, both natural and engineered, allow one to consume these resources, dispose of wastes, and sometimes breath clean unpolluted air? Most citizens have not thought about these issues. In fact, humans who are disconnected from Nature are sadly, so ignorant of the world we live in, that they are not able to propose solutions when new problems arise. They can not contribute to society. Surely, our educational systems should and can impart a basic understanding of how life is supported in our common, shared biosphere. And this can not be only at a minimal level. There is a need for in-depth understanding of the key issues.

One of the great failings of our educational systems is that too many of us never acquire a knowledge of the biogeochemical cycles that sustain life on Earth. Without this knowledge and familiarity with how our activities alter these interconnected cycles, no one is in a position to understand the most important problems facing mankind in today's world. Perhaps not coincidentally, uninformed world citizens also seem to lack an understanding of the most basic laws of thermodynamics that govern the activities of all the cells in our bodies, and, in fact, govern the functioning of the entire universe. Again, we understand the arguments that no one can know everything, and that it is simply unimportant to our immediate lives to know such details. But what does such knowledge allow for humanity, that otherwise would not be possible? People who lack an understanding of science and the workings of the world will never be in a position to help solve society's most pressing problems. So who will be in a position to solve them? Only the best educated; the most knowledgeable, and the best integrated citizens. Truly, we need enlightened leadership. We shudder to think that our future leaders, like those of the recent past, might neglect their responsibilities until it is too late. 